\title{
Effect of Rice Bran on Productivity, Hatchability and Yolk and Blood Lipid Profile of Laying Japanese Quail
}

\author{
H. S. Zeweil, S. M. Zahran, M. H. Ahmed, W. M. Dosoky and H. Leftah \\ Department of Animal and Fish Production, Faculty of Agriculture (Saba Basha), \\ Alexandria University.
}

*Corresponding author: hszeweil@yahoo.com

\begin{abstract}
A total number of 216 female and 108 male Japanese quail at 14 wks of age were used in a 7-week-trial to investigate the effect of rice bran on the quality and quantity of egg production as well as blood lipid profile. There were three dietary treatment groups: a control group fed on a corn-soybean based diet, 12.5 and $25.0 \%$ rice bran diets. Results showed that egg laying rate, egg weight, egg mass and feed conversion ratio were insignificantly affected by treatments. Egg quality insignificantly affected by different treatments. The results showed significant decrease in egg yolk total lipids and cholesterol due to inclusion of rice bran in the diets in comparison with the control group. Hatchability and fertility was not influenced by different treatments. Blood serum total lipids, triglycerides, low density lipoprotein were significantly decreased, however, high density lipoprotein increased with increasing level of rice bran in the diet. Rice bran treatments showed significant $(P \leq 0.01)$ increase in concentration of TAC than control group reached to 32.6 and $66.3 \%$ for birds fed 12.5 and 25 $\%$ rice bran containing diets, respectively. Numerical increase in glutathione peroxidase in the group given 12.5 and $25 \%$ rice bran containing diet as compared to the control group. In conclusion, egg laying rate and egg quality insignificantly affected by rice bran, however, the results showed significant improvements in blood and egg lipid profile, beside the antioxidative status as a result of inclusion fresh rice bran in the diet.
\end{abstract}

Key words: Quail, rice bran, laying performance, egg quality, lipid profile

\section{INTRODUCTION}

Chicken eggs are recognized as a perfect source of protein, lipids, vitamins and other valuable nutrients, but eggs also contain a high level of cholesterol, which is strongly associated with cardiovascular diseases. The current recommended level for daily intake of cholesterol is less than $300 \mathrm{mg}$ and people often limit their egg consumption to avoid increases in the blood cholesterol levels (AHA, 1996; Carrillo-Domínguez et al., 2005). Therefore, approach to reduce the cholesterol content in eggs not only helps to improve public health efforts, but it can also be beneficial for the egg industry. Recently, dietary supplementations of probiotic strains (Abdelqader et al., 2013; Lei et al., 2013; Zeweil et al., 2016), vegetable oils (Zeweil et al., 2013) and fiber feed ingredients (Olgun and Yıldız (2015) have already been used to regulate the egg yolk cholesterol concentration.

Rice bran, a major by-product from the rice milling process, has been used as an ingredient in livestock feed. It is probably the most widely used cereal by-product available. The feeding value of rice bran used as an ingredient in poultry feed has been reviewed by Farrell (1994). Because of its high oil content $(20 \%)$, rice bran is poorly metabolized by young birds (Warren and Farrell, 1990). Rice bran oil contains a high concentration of unsaturated fatty acids $(80-85 \%)$ which easily become rancid, especially under warm and humid climatic conditions. Hussein and Kratzer (1982) found that the free fatty acid content of rice bran fat was increased from $13.7 \%$ before storage to $42.8 \%$ 
during 3-month storage period. Srinivasan et al. (2007) demonstrated that dietary rice bran is an excellent source of phytochemicals with antioxidative properties, such as $\beta$-sitosterol and a wide variety of phenolics and carotenoids. Ferulic acid, a well-studied phenolic compound, has been shown to be an effective scavenger of superoxide anion radicals and inhibitor of lipid peroxidation. Calabrese et al. (2008) demonstrated that ferulic acid protected against hydrogen peroxide-induced cellular damage through increased cellular levels of heme oxygenase-1 and heat shock protein-70. A limited number of studies have been conducted to evaluate the feeding value of rice bran for Japanese quail. Studies with other poultry species have shown that layer chickens and ducks can tolerate as high as $40 \%$ dietary rice bran while broilers can tolerate a maximum of $20 \%$ (Farrell, 1994). These differences may be attributed to the extent to which respective species/type of poultry can tolerate the anti-nutrients such as phytate, fibre, anti-proteolytic substances and lipase present in rice bran. Therefore, this study aimed to investigate the effect of rice bran,(not stored more than 14 day) on the quality and quantity of egg production as well as blood lipid profile in Japanese quail laying hens.

\section{MATERIALS AND METHODS}

This study was carried out at the Poultry Research Laboratory belonging to Animal and Fish Production Department, Faculty of Agriculture (Saba Basha), Alexandria University.

Three hundred and twenty-four (216 females and 108 males) Japanese quail of 14 weeks-old which had been in production for $v_{\text {weeks }}$ were weighed and randomly allocated in a completely randomized design considering three treatments groups, 108 birds each ( 72 females and 36 males), and each in three replicate per treatment. The birds were selected on the basis of more than $70 \%$ egg production rate after a two-week observation period. All birds were reared under similar hygienic and managerial conditions. Rice bran was included at levels of $0,12.5$ and $25.0 \%$ and fed to 21 weeks of age. The samples of rice bran were obtained from the milling of rice (Oryza sativa L.) namely Sakha 104 a popular short grain Japonica cultivar for the consumption in Egypt. Rice bran obtained from the milling of rice 4 times and each not stored more than 14 days. The composition and calculated analysis of the experimental diets are shown in Table (1). Fresh feed was mixed weekly and not stored for more than one week. The hens were reared in wire batteries under similar environmental conditions. All birds had full access to feed and fresh water. The photoperiod was 16 hours of light per day throughout the experimental period, which lasted for 7 weeks from January to February. Records were kept for egg number, egg laying rate, feed consumption, egg weight and average body weight change. Measurements of egg quality were taken on average of 21 eggs from each treatment and were performed through two consecutive days per month. Yolk cholesterol was extracted and measured by the method of Folch et al. (1956) as modified by Washburn and Nix (1974) from three eggs of each replicate. 
Table (1). Composition and calculated analysis of the experimental diets.

\begin{tabular}{lccc}
\hline \multicolumn{1}{c}{ Ingredients } & \multicolumn{3}{c}{ Rice bran \% } \\
\cline { 2 - 4 } & $\mathbf{0}$ & $\mathbf{1 2 . 5}$ & $\mathbf{2 5}$ \\
\hline Yellow corn & 59.40 & 50.00 & 40.05 \\
Soybean meal (44 \%) & 22.8 & 20.30 & 17.50 \\
Concentrate (50 \%) ** & 10.00 & 10.00 & 10.00 \\
Di-calcium phosphate & 0.30 & 0.20 & 0.20 \\
Limestone & 5.50 & 5.25 & 5.28 \\
Sunflower oil & 1.00 & 0.75 & 1.00 \\
Vit. and min. mix. & 0.50 & 0.50 & 0.50 \\
Salt (NaCl) & 0.50 & 0.50 & 0.50 \\
Rice bran ${ }^{1}$ & 0.00 & 12.50 & 25.00 \\
Total & 100 & 100 & 100 \\
\hline & Calculated analyses & \\
\hline Crude protein, \% & 20.08 & 19.93 & 19.60 \\
ME (Kcal/ Kg diet) & 2905 & 2879 & 2874 \\
Ether extract, \% & 2.59 & 4.30 & 5.52 \\
Crude fiber, \% & 3.05 & 4.07 & 5.07 \\
Methionine, \% & 0.41 & 0.73 & 0.66 \\
Methionine + cystine, \% & 0.56 & 0.57 & 0.58 \\
Lysine, \% & 1.03 & 1.01 & 1.00 \\
Calcium, \% & 2.96 & 2.85 & 2.85 \\
Av. Phosphorus, \% & 0.38 & 0.38 & 0.39 \\
\hline
\end{tabular}

*Each kg of vitamin and minerals mixture contained: Vit. A, 4,000,000 IU; Vit. D3, 500,000 IU; Vit, E, 16.7 g., Vit. K, 0.67 g., Vit. B1, 0.67 g., Vit. B2, 2 g., Vit. B6, 0.67 g., Vit. Bi2, 0.004 g., Nicotinic acid, 16.7 g., Pantothenic acid, 6.67 g., Biotin, 0.07 g., Folic acid, 1.67 g., Choline chloride, 400 g., Zn, 23.3 g., Mn, 10 g., Fe, 25 g., Cu,1.67 g., I, 0.25 g.,Se, 0.033 g.,Mg, 133.4 g.

** Concentrate: ME (K cal $/ \mathrm{kg}$ ) 2870 , Crude protein $50 \%$, Crude fiber $1.19 \%$, Crude fat $6.16 \%$, Calcium 7.3\%, Phosphorus 3.2\%, NaCl 1.44\%, Methionine 1.65\%, Methionine \& Cystine $1.98 \%$, Lysine $2.58 \%$.

Rice bran contain $14 \%$ crude protein; $3980 \mathrm{ME} / \mathrm{kg} ; 0.59 \%$ lysine; $0.26 \%$ methionine; $0.35 \%$ methionine + cystine; $0.07 \%$ calcium; $0.22 \%$ available phosphorus; $11.4 \%$ crude fiber; $13.0 \%$ crude fat.

${ }^{2}$ According to NRC (1994).

Eggs were collected during the 21 week of age for 7-day period and were stored in an egg room at $15.5^{\circ} \mathrm{C}$ dry bulb and $70 \%$ relative humidity. They were incubated at $37.6{ }^{\circ} \mathrm{C}$ and relative humidity was $55-60 \%$ and hatched at $37.3{ }^{\circ} \mathrm{C}$ and relative humidity was $65-70 \%$ in automatic incubators. The removed eggs and eggs not hatched on day 18 were broken to differentiate infertile eggs from those containing dead embryos. Fertility was calculated as number of fertile eggs as relative to total number of eggs set; meanwhile hatchability was calculated as number of healthy hatched chicks as relative to total fertile number of eggs set; embryonic mortality percentage expressed as percentage of fertile eggs set was recorded on day 18 to differentiate the first and second embryonic death. Blood samples from the brachial vein of 4 hens in each treatment were drawn and serum were obtained by centrifugation of blood at 3500 r.p.m. for $15 \mathrm{~min}$. and kept at $-18^{\circ} \mathrm{C}$ until analyzing. Serum total protein, albumin, total lipids, cholesterol, low density lipoprotein, high density lipoprotein, total antioxidant capacity and glutathione peroxidase were, calorimetrically, determined using commercial kits (from Biomerieux, Poains, 
France). The proximate analysis of feed was carried out according to A O A C (2000). Data was statistically analyzed according to SAS program (SAS Institute, Inc., 1994) using general linear model (GLM) and the significant differences among treatments were determined using Duncan's multiple range test (Duncan, 1955).

\section{RESULTS AND DISCUSSIONS}

Results presented in Table 2 showed that different levels of rice bran inclusion in the diet had no significant effects on egg laying rate, egg weight, egg mass and feed conversion ratio as compared with the control. However, body weight change was significantly decreased in the groups given 12.5 and $25 \%$ rice bran containing diets in comparison with the control group, even they consumed more feed comparing to the control. These results were in agreement with those of Amoah and Martin (2010) who reported that performance of laying type quail fed $20 \%$ full fat rice bran was comparable with those fed control diet. On the other hand, Abeyrathna et al. (2014) reported that the total egg production of quail fed diet containing $40 \%$ rice bran was significantly lower than that of birds fed 20 and $30 \%$ of rice bran.

The results in Table 3 showed that egg weight, specific gravity, percentage of albumin weight, egg shape index, yolk weight, yolk weight percentage and yolk color were not significantly affected by rice bran inclusion in the diet. On the other hand, absolute albumen weight was significantly $(P \leq 0.05)$ increased with $12.5 \%$ rice bran containing diet than the group fed control diet, also, the group given $25 \%$ rice bran increased absolute albumin weight, but the increase was not significant. Significant $(P \leq 0.01)$ decrease in albumin height in the group received $25 \%$ rice bran was recorded as compared to the group had $12.5 \%$ rice bran, , however, the groups had 12.5 and $25 \%$ rice bran in their diets was not significantly differ in comparison with the control group. Significant $(P \leq$ 0.05 ) increase in yolk index was observed in the group received $25 \%$ rice bran in their diet in comparison with control group, while the group given $12.5 \%$ rice bran diet did not different significantly than the control group. Egg shell weight was significantly $(P \leq 0.05)$ deteriorated by increasing the level of rice bran in the diet and this deterioration reached significant with $25 \%$ rice bran diet in comparison with the control group. The results showed also numerical deterioration in egg shell percentage and egg shell thickness due to increasing level of rice bran in the diet. The results obtained by Nobakht (2007) stated that egg quality did not significantly affected by inclusion different levels of rice bran in laying hen diets. The results obtained by Hagnazar and Rezaei (2004) indicated also that there were insignificant difference in egg quality with inclusion rice bran in laying hen diets up to $25 \%$. The same results were obtained by Filardi et al. (2007) reported that the inclusion of rice bran up to $15 \%$ in the diet had no negative effect on egg quality of commercial laying hens. On the other hand, Ademola et al. (2012) reported that laying hens fed diet containing $20 \%$ rice bran had the best Haugh units, shell thickness, yolk and shell weights as compared to laying hens fed $40 \%$ rice bran containing diet. Also, Samli et al. (2006) showed that Haugh units significantly improved by using up to $15 \%$ rice bran in laying hen diets. 
Table (2). Performance of laying Japanese quail hens fed on the experimental diets.

\begin{tabular}{lcccc}
\hline \multirow{2}{*}{ Parameters } & \multicolumn{4}{c}{ Rice bran \% } \\
\cline { 2 - 5 } & $\mathbf{0}$ & $\mathbf{1 2 . 5}$ & $\mathbf{2}$ & P value \\
\hline Body weight change, g & $8.04 \pm 2.68$ & $-6.36 \pm 3.82^{\mathrm{b}}$ & $-6.51 \pm 2.84^{\mathrm{b}}$ & 0.001 \\
Egg production, \% hen-da y & $76.91 \pm 2.11$ & $76.22 \pm 2.50$ & $74.18 \pm 2.44$ & 0.692 \\
Egg number, hen/day & $0.77 \pm 0.02$ & $0.76 \pm 0.02$ & $0.74 \pm 0.02$ & 0.629 \\
Mean egg weight, g & $13.23 \pm 0.16$ & $13.45 \pm 0.14$ & $13.33 \pm 0.12$ & 0.429 \\
Egg mass/hen/day, g & $10.16 \pm 0.25$ & $10.27 \pm 0.41$ & $9.87 \pm 0.26$ & 0.653 \\
Feed consumed /hen /day, g & $32.31 \pm 0.50^{\mathrm{b}}$ & $34.08 \pm 0.31$ & $33.43 \pm 0.45^{\mathrm{ab}}$ & 0.026 \\
Feed conversion ratio & $3.18 \pm 0.08$ & $3.34 \pm 0.14$ & $3.39 \pm 0.08$ & 0.392 \\
\hline ab.. Means having the different small letters in each row are differ significantly $(\mathrm{P} \leq 0.05)$
\end{tabular}

Table (3). Egg quality and egg yolk lipid profile of laying Japanese quail hens fed on the experimental diets.

\begin{tabular}{|c|c|c|c|c|}
\hline \multirow{2}{*}{ Parameters } & \multicolumn{3}{|c|}{ Rice bran \% } & \multirow{2}{*}{$\begin{array}{c}\mathbf{P} \\
\text { value }\end{array}$} \\
\hline & $\mathbf{0}$ & 12.5 & 25 & \\
\hline Egg weight, $\mathbf{g}$ & $13.38 \pm 0.19$ & $13.67 \pm 0.21$ & $13.14 \pm 0.19$ & 0.1737 \\
\hline Egg specific gravity & $1.074 \pm 0.001$ & $1.074 \pm 0.001$ & $1.074 \pm 0.001$ & 0.8449 \\
\hline Albumen height, $\mathrm{mm}$ & $2.62 \pm 0.08^{\mathrm{ab}}$ & $2.91 \pm 0.13$ & $2.43 \pm 0.12^{\mathrm{b}}$ & 0.0063 \\
\hline Albumen weight, g & $5.85 \pm 0.18^{b}$ & $6.36 \pm 0.15$ & $5.89 \pm 0.15^{\mathrm{ab}}$ & 0.0543 \\
\hline Albumen ,\% & $43.68 \pm 1.13$ & $46.74 \pm 1.13$ & $44.85 \pm 1.04$ & 0.1550 \\
\hline Yolk weight, g & $4.28 \pm 0.07$ & $4.30 \pm 0.08$ & $4.25 \pm 0.08$ & 0.931 \\
\hline Yolk & $32.12 \pm 0.63$ & $31.55 \pm 0.55$ & $32.49 \pm 0.61$ & 0.541 \\
\hline Yolk c & $3.69 \pm 0.09$ & $3.51 \pm 0.13$ & $3.51 \pm 0.11$ & 0.4396 \\
\hline Yolk i & $420.92 \pm 1.05^{b}$ & $449.59 \pm 1.02^{\mathrm{ab}}$ & $472.90 \pm 0.66$ & 0.006 \\
\hline hell weight, $\mathbf{g}$ & $1.151 \pm 0.022$ & $1.117 \pm 0.019^{\mathrm{ab}}$ & $1.084 \pm 0.017^{b}$ & 0.0550 \\
\hline Egc & $8.625 \pm 0.153$ & $8.219 \pm 0.162$ & $8.277 \pm 0.133$ & 0.1194 \\
\hline Egg shell thickness, mm & $0.246 \pm 0.004$ & $0.243 \pm 0.004$ & $0.244 \pm 0.004$ & 0.8157 \\
\hline \multicolumn{5}{|c|}{ Egg yolk lipid profile: } \\
\hline Total It & $307.05 \pm 7.37$ & $270.03 \pm 4.40^{b}$ & $227.37 \pm 1.721^{\mathrm{c}}$ & 0.0001 \\
\hline Total cholesterc & $12.57 \pm 0.17$ & $11.81 \pm 0.21^{\mathrm{b}}$ & $11.76 \pm 0.18^{b}$ & 0.005 \\
\hline
\end{tabular}

The obtained results showed significant decrease $(P \leq 0.01)$ in egg yolk total lipids and cholesterol due to rice bran inclusion in the diets in comparison with the control group. Our results were in agreement with the results presented by Dung et al. (2012) reported that levels of 2.5 and $3 \%$ of rice bran oil had beneficial effect on lowering egg yolk cholesterol. But the results of Safamehr and Attarhoseini (2011) and Abeyrathna et al. (2014) showed that inclusion of the rice bran in laying hens diets did not significantly influence cholesterol in egg yolk as compared with the control group.

In the present study, hatchability and fertility was not influenced by different treatments (Table 4). Also, the results of Awad et al. (2011) showed no significant differences were found among groups fed diets contained rice bran at levels of 16 and $24 \%$ as compared to those of the control for egg fertility, hatchability, early and late embryonic mortality percentages and chick weights. 
Table (4). Fertility and hatchability traits of Japanese quail hens fed on the experimental diets.

\begin{tabular}{lcccc}
\hline \multicolumn{1}{c}{ Parameters } & \multicolumn{3}{c}{ Rice bran \% } & \multirow{2}{*}{ P value } \\
\cline { 2 - 5 } & $\mathbf{0}$ & $\mathbf{1 2}$ & $\mathbf{2 5}$ & \\
\hline Fertility, \% & $90.19 \pm 0.99$ & $90.83 \pm 0.62$ & $90.78 \pm 1.12$ & 0.896 \\
Hatchability, \% & $82.43 \pm 1.17$ & $85.43 \pm 1.70$ & $83.72 \pm 1.15$ & 0.350 \\
Early embryonic death, \% & $1.87 \pm 0.54$ & $2.03 \pm 0.58$ & $2.27 \pm 0.61$ & 0.901 \\
Late embryonic death, \% & $3.48 \pm 0.79$ & $2.86 \pm 0.74$ & $2.83 \pm 0.77$ & 0.793 \\
Hatch chick weight,g \% & $8.97 \pm 0.10$ & $9.09 \pm 0.19$ & $9.09 \pm 0.14$ & 0.880 \\
\hline
\end{tabular}

Blood serum total lipids, triglycerides, low density lipoprotein were significantly decreased, however, high density lipoprotein increased with increasing level of rice bran in the diet (Table 5). The increase in high density lipoprotein concentration reached to 30.5 and $34.4 \%$ for birds fed 12.5 and 25 $\%$ rice bran containing diets, respectively. On the other hand, the obtained results showed that different levels of rice bran had insignificant effect on total cholesterol concentrations as compared with the control group. Dung et al. (2012) indicated that crude rice bran oil is a rich source of phytoceuticals such as, oryzanol, tocopherols, tocotrinols and linoleic acid. Gamma oryzanol is one of a component having antioxidant property. The role of gamma oryzanol in decreasing plasma or serum cholesterol was showed by Kahlon (1992a, b), lowering cholesterol absorption, decreasing platelet aggregation and lowering LDL-cholesterol were well documented (Patel and Naik, 2004).

Table (5). blood Serum lipid profile, total antioxidant capacity and glutathione peroxidase of laying Japanese quail hens fed on the experimental diets.

\begin{tabular}{|c|c|c|c|c|}
\hline \multirow{2}{*}{ Parameters } & \multicolumn{3}{|c|}{ Rice bran \% } & \multirow{2}{*}{$P$ value } \\
\hline & 0 & 12.5 & 25 & \\
\hline Total lipids (mg/dl) & $716.00 \pm 29.98$ & $599.88 \pm 30.00^{b}$ & $639.44 \pm 28.37^{b}$ & 0.007 \\
\hline Triglycerides (mg/dl) & $335.22 \pm 24.17$ & $208.33 \pm 20.40^{c}$ & $258.00 \pm 25.28^{b}$ & 0.0001 \\
\hline Cholesterol (mg/dl) & $179.44 \pm 3.02$ & $173.50 \pm 2.78$ & $178.20 \pm 4.26$ & 0.232 \\
\hline Low density lipoprotein (mg/dl) & $49.66 \pm 1.13$ & $49.22 \pm 1.52$ & $42.22 \pm 1.09^{b}$ & 0.0001 \\
\hline High density lipoprotein(mg/dl) & $62.66 \pm 3.51^{b}$ & $81.77 \pm 5.02$ & $84.22 \pm 6.43$ & 0.0051 \\
\hline Totalantioxidantcapacity(mm/L) & $0.89 \pm 0.04^{c}$ & $1.18 \pm 0.14^{b}$ & $1.48 \pm 0.09$ & 0.001 \\
\hline Glutathioneperoxidase(nmol/ml) & $45.44 \pm 5.71$ & $49.56 \pm 7.41$ & $54.33 \pm 8.06$ & 0.593 \\
\hline
\end{tabular}

The results presented by Abd El-Hady (2013) reported that, full fat rice bran is more effective in cholesterol lowering than either rice bran oil or defatted rice bran, certainly due to the presence of comparatively high levels of tocopherol, tocotrienol and oryzanol as well as unsaponifiables. These results are supported by those of Minhajuddin et al. (2005), Wilson et al. (2007) and Zigoneanu et al. (2008). Also, Abd El-Hady (2013) observed that, full fat rice bran showed slight improvement in serum HDL-cholesterol of rats followed by rice bran oil and defatted rice bran in comparison with the control group. 
The results illustrated in Table 5 showed significant $(P \leq 0.01)$ decrease in serum total antioxidant capacity (TAC) in the control group, however, inclusion of rice bran showed significant $(P \leq 0.01)$ increase in concentration of total antioxidant capacity surpassed the control one by 32.6 and $66.3 \%$ for birds fed 12.5 and $25 \%$ rice bran containing diets, respectively. The results of Liang et al. (2014) reported that lipid oxidation can be prevented by rice bran oil in poultry muscle, due to having different compounds such as: gamma-oryzanol, tocotrienols, tocopherols and squalene. Seifi et al. (2015) showed that the decrease of TBARS values in chicken muscle which has been injected by rice bran oil may be due to the increase of the ratio of other components like tocopherol, tocotrienol, and oryzanol in the products that come from rice bran oil. Kim et al. (2000) and Chae et al. (2002) demonstrated that rancid rice bran reduced TBARS value in chicken meat.

Glutathione peroxidase was insignificantly affected by rice bran levels, however, it was observed numerical increase in glutathione peroxidase in the group given 12.5 and $25 \%$ rice bran containing diet. This increase surpassed the control one by 9.1 and $19.6 \%$, respectively. Seifi et al. (2015) found that the level of glutathione was higher either in muscle or heart in that group which has been injected by rice bran oil into the yolk as compared to control group. These results also confirmed the antioxidant capacity power of rice bran oil (ÖztürkÜrek et al., 2001).

In conclusion, egg laying rate and egg quality insignificantly affected by rice bran, however, the results showed significant improvements in blood and egg yolk lipid profile and diminished oxidative status as a result of inclusion fresh rice bran in the diet. A number of human (Lai et al., 2012; Mäkynen et al., 2012) and animal (Mobarak et al., 2010) studies have shown that rice bran and rice bran oil have hypocholesterolemic effects, results of this experiment suggested that such an effect does exist in laying Japanese quail.

\section{REFERENCES}

Abd El-Hady, Sahar R. (2013). Effects of stabilized (rice bran, defatted rice bran and rice bran oil) on serum lipid parameters and blood glucose levels in rats. J. Food and Dairy Sci., Mansoura Univ., 4 (6): $269-280$.

Abdelqader, A., R. Irshaid and A.R. Al-Fataftah (2013). Effects of dietary probiotic inclusion on performance, eggshell quality, cecal microflora composition, and tibia traits of laying hens in the late phase of production. Trop. Anim. Health Prod. 45:1017-1024.

Abeyrathna, H. M. W. N., N.S.B.M. Atapattu and W.W.D.A. Gunawardane (2014). Effects of the level of dietary rice bran with or without phytase, on performance and egg parameters of laying Japanese quail. Tropical Agricultural Research Vol. 26: 39-47.

Ademola, S. G., T. Elawal, O. O. Egbewande, A. O. Basher, A. A. Ajayi and A. O. Oyegbade (2012). Performance, Egg Quality, Haematological Indices and Cost-Benefit Analysis of Laying Hens fed Palm Kernel Meal and Varying Levels of Rice Bran Diets Supplemented with Maxigrain. World J Life Sci. and Medical Research,2(3):128-133. 
AHA, American Heart Association (1996). Dietary guidelines for healthy Americans. Circulation 94: 1795-1800.

Amoah, J.K. and E. A. Martin (2010). Quail (Coturnix coturnix japonica) layer diets based on rice bran and total or digestible amino acids, J Appl Biosci, 26: 1647 - 1652.

AOAC.(2000). Official methods of analysis 15th ed A.O.A.C. Washington, DC.

Awad, A. L., M. A. A. Hussein, A. I. A. Ghonim and M. G. Kasim (2011). Effect of dietary inclusion level of distillers dried grains with solubles (DDGS) on laying performance in Domyati ducks. . Egypt Poult. Sci. , 31:51-63.

Calabrese V, S. Calafato, E. Puleo, C. Cornelius, M. Sapienza, P. Morganti and C. Mancuso (2008). Redox regulation of cellular stress response by ferulic acid ethyl ester in human dermal fibroblasts: role of vitagenes. Clin Dermatol. 26:358-363.

Carrillo-Domı́nguez, S., M. E. Carranco-Jauregui, R. M. CastilloDomı́nguez, M. I. Castro-Gonza'lez, E. Avila-Gonza'lez and F. Pe'rez-Gil (2005). Cholesterol and $n-3$ and $n-6$ fatty acid content in eggs from laying hens fed with red crab meal (Pleuroncodes planipes). Poultry Science, Vol. 84: 167-172.

Chae, B., K. Lee and S. Lee (2002). Effects of feeding rancid rice bran on growth performance and chicken meat quality in broiler chicks. Asian Australasian Journal of Animal Sciences 15: 266-273.

Duncan, D B. (1955).Multiple range and F., test Biometric. 11:42.

Dung, N. N. X., L. T. Phuong, N. M. Suong and L. H. Manh (2012). Effect of crude rice bran oil supplementation on performance, egg production and quality, plasma lipid and yolk cholesterol of laying hens; Proceedings of the International Conference "Livestock-Based Farming Systems, Renewable Resources and the Environment", 6-9 June 2012, Dalat, Vietnam.

Farrell, D.J. (1994). Utilization of rice bran in diets for domestic fowl and ducklings.World's Poultry Science Journal 50:115-131.

Filardi, R, O. Junqueira, A. C. Laurentiz, E. M. Casartelli, V. Assuena, J. Pileggi and K. F. Duarte (2007). Utilização do farelo de arroz em rações para poedeiras comerciais formuladas com base em aminoácidos totais e digestíveis. Ciência Animal Brasileira, Vol. 8: 397-405.

Folch, J., M. Lees and G.H. Sloane-Stanley (1956). Asimple method for the isolation and purification of total lipids from animal tissues. J. Biol. Chem., 226: 497.

Haghnazar, A. and M. Rezaei (2004). To determine the metabolizable energy of rice bran and the use of it in layer ration. XII. World's Poult. Cong. Istanbul, Turkey, pp: 8-13.

Hussein, A.S. and F. H. Kratzer (1982). Effects of rancidity on the feeding value of rice bran for chickens. Poultry Science 61: 2450-2455.

Kahlon, T. S., F. I. Chow, N. R. Sayre and A. A. Betschart (1992a). Cholesterol lowering in hamsters fed rice bran at various levels, defatted rice bran and rice bran oil. J .Nutr. 122:513-519.

Kahlon, T. S., R. M. Saunders, R. N. Sayre, F. I. Chow, M. M. Chiu and A. A. Betschart (1992b). Cholesterol-lowering effects of rice bran and rice 
bran oil fractions in hypercholesterolemic hamsters. Cereal Cheni. 69:485-489.

Kim, J. S., J. Godber and W. Prinaywiwatkul (2000). Restructured beef roasts containing rice bran oil and fiber influences cholesterol oxidation and nutritional profile. Journal of Muscle Foods 11: 111-127.

Lai, M.H., Y. T. Chen, Y. Y. Chen, J. H. Chang and H. H. Cheng (2012). Effects of rice bran oil on the blood lipids profiles and insulin resistance in type 2 diabetes patients. J. Cli. Biochem. and Nutri. 51(1): 15 - 18.

Lei, K., Y.L. Li, D.Y. Yu, I.R. Rajput and W.F. Li (2013). Influence of dietary inclusion of Bacillus licheniformis on laying performance, egg quality, antioxidant enzyme activities, and intestinal barrier function of laying hens. Poultry Sci., 92:2389-2395.

Liang, Y., Y. Gao, Q. Lin, F. Luo, W. Wu, Q. Lu and Y. Liu (2014). A review of research progress on the bioactive ingredients and physiological activities of rice bran oil. European Food Research and Technology, 238: 169-176.

Mäkynen, K., C. Chitchumroonchokchai S. Adisakwattana, M. Failla and T. Ariyapitipun (2012). Effect of gamma-oryzanol on the bioaccessibility and synthesis of cholesterol. Eur Rev Med Pharmacol Sci., 16(1): 49 56.

Minhajuddin, M., Z.H. Beg and J. Iqbal. ( 2005). Hypolipidemic and antioxidant properties of tocotrienol rich fraction isolated from rice bran oil in experimentally induced hyperlipidemic rats. Food Chemical Toxicol., 43:747-753.

Mobarak, E.A., A. S. El-Shazly and A. S. Barakat (2010). Effect of supplementing balady bread with rice bran on the high blood glucose and cholesterol levels. Mansoura University Journal of food and dairy Sciences, 1 (5): $253-266$

Nobakht, A. (2007). The effect of inclusion different levels of rice bran in laying hens diets on performance and plasma and egg yolk cholesterol contents. J. Anim. Vet. Adv., 6 (9): 1120-1124.

Olgun, O. and A. Ö. Yıldız (2015). Effect of Dietary Alfalfa Meal on Performance, Egg Quality, Egg Yolk Cholesterol and Hatchability Parameters of Quail Breeders. Turkish Journal of Agriculture - Food Science and Technology, 3(3): 103-106.

Öztürk-Ürek, R., L. A. Bozkaya and L. Tarhan (2001). The effects of some antioxidant vitamin and trace element supplemented diets on activities of SOD, CAT, GSHPx and LPO levels in chicken tissues. Cell Biochemistry and Function 19: 125-132.

Patel, M. and S. N. Naik (2004). Gamma-oryzanol from rice bran oil-A Review. J Sci Ind Research 63: 569-578.

Safamehr, A. and H. Attarhoseini (2011). Effects of Rice Bran and Phytase Supplementation on Performance, Egg Quality, and Biochemical Parameters of Comercial Hy-Line Hens. ranian Journal of Applied Animal Science., 1 (3): 169- 176.

Samli, H. E., N. Senkoylu, H. Akyurek and A. Agma (2006). Using rice bran in laying hen diets Journal of Central European Agriculture , 7 (1): 137-140.

SAS Institute Inc (1994). SAS/STAT® User's Guide: Statistics. ver. 6.04, Fourth Edition SAS Institute Inc., Cary, NC. 
Seifi, S., A. Araghi, R. Sayrafi and A. Salehi (2015). Effects of rice bran oil on qualitative properties of heart and breast muscle tissues in chicken embryo model. International Food Research Journal , 22(5): 1894-1897.

Srinivasan, M., A. R. Sudheer and V. P. Menon (2007). Ferulic acid: therapeutic potential through its antioxidant property. J Clin Biochem Nutr., 40:92-100.

Warren, B.E. and D. J. Farrell (1990). The nutritive value of full-fat and defatted Australian Rice Bran. 1. Chemical Composition. Animal Feed Science and Technology , 27: 219-228.

Washburn, K.W. and D. F. Nix (1974). A rapid technique for extraction of yolk cholesterol. J. Poult. Sci., 53: 1118-1122.

Wilson, T.A., R.J. Nicolosia, B. Woolfreya and D. Kritchevsky (2007). Rice bran oil and oryzanol reduce plasma lipid and lipoprotein cholesterol concentrations and aortic cholesterol ester accumulation to a greater extent than ferulic acid in hypercholesterolemic hamsters. J. Nutr. Biochem., 18:105-112.

Zeweil , H. S, Y. Z. Eid, S. Zahran, W. Dosoky, Salma H. Abu Hafsa and Girges, Amal (2016). Effect of different levels of aspergillus awamori as probiotic on the production and egg quality of laying Japanese quail under summer conditions. Egypt. Poult. Sci. , 36 (I): 53-66.

Zeweil, H. S., R. E. Rizk, M. H. Abd El- Rahman, N.A. Mohamed, and E.E Iraky. (2013). Influence of dietary linseed oil and selenium supplementation on productive and reproductive performance of Bandarah chickens. $11^{\text {th }}$ World Conference on Animal Production, Beijing, China, 15-20 October 2013.

Zigoneanu, I. G., L. Williams, Z. Xu and C. M. Sabliov (2008). Determination of antioxidant components in rice bran oil extracted by microwaveassisted method. Bioresource Tech., 99: 4910-4918.
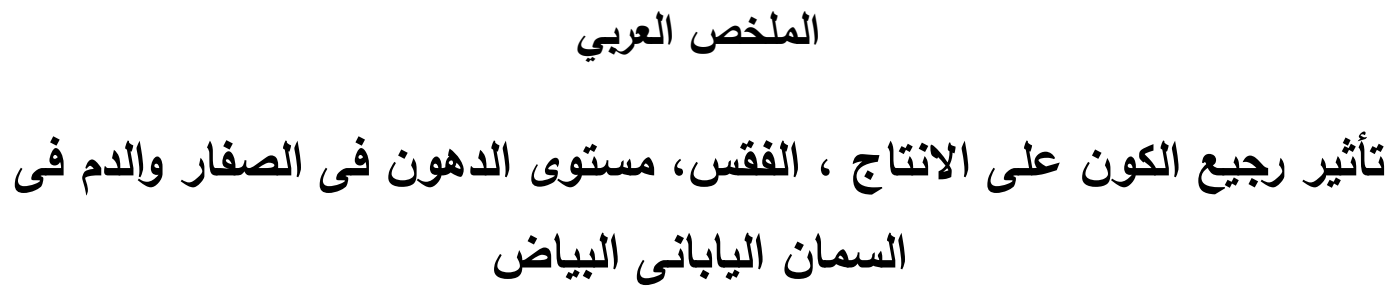

حسن زويل ، سليمان زهران ، محمد حسن ، وليل دسوقي ، حيدر لقته

جامعه الإسكندرية - كليه الزراعة - سابا باشا - قسم الانتاج الحيواني والسمكي

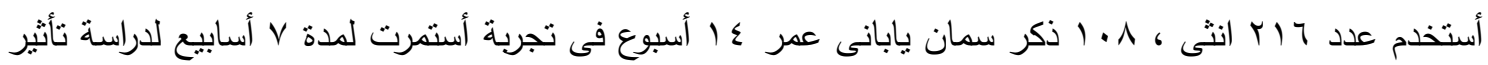
أضافة رجيع الكون فى العليقة على جودة ومعدل انتاج البيض بالاضافة الى تأثيره على دهون الدم وصفار البيض. أستخدمت ثلاث معاملات غذائية ، مجموعة كونترول ضابطة تتاولت عليقة من الذرة الصفراء وكسب الصباء الصويا،

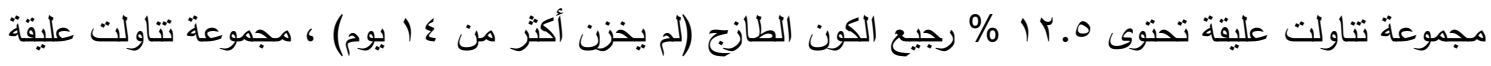
تحتوى 0r \% رجيع الكون الطازج. أوضحت النتائج أن معدل انتاج البيض ، وزن البيض، كتلة البيض، والكفاءة 
التحويلية لم تتأثر بالمعاملات المختلفة. لوحظ انخفاض في الدهون الكلية وكولسترول صفار البيضة نتيجة أضافة رجيع الكون فى العليقة مقارنة مع المجموعة الضابطة. لم يتأثر كل من نسبة الخصوبة والفقس بالمعاملات

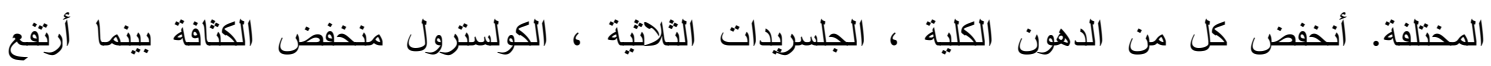
الكولسترول مرتفع الكثافة نتيجة لاحتواء العليقة على رجيع الكون الطازج. معاملات رجيع الكون أدت الى زيادة

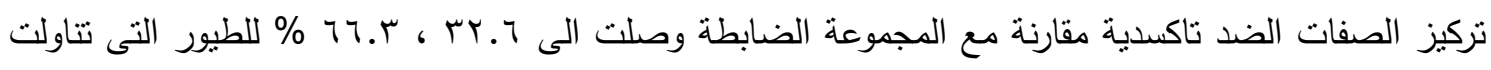

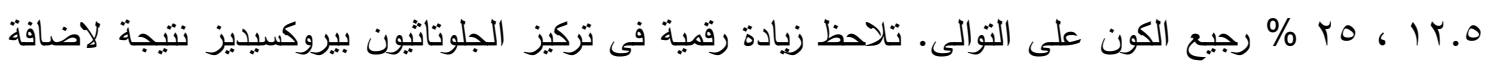

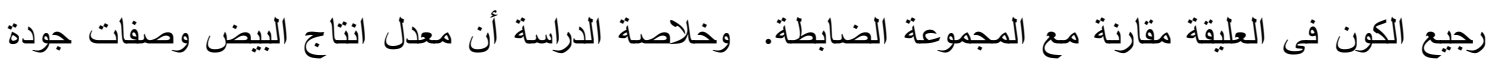
البيض لم تتأثر برجيع الكون ولكن تلاحظ تحسن معنوى فى محتوى الدم وصفار البيض من الدهون بجانب

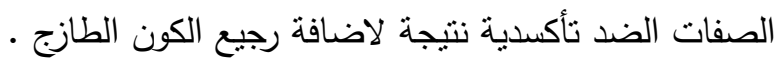


